\title{
Efektivitas pembelajaran ilmu nagham Al-Qur'an di Institut Ilmu Al-Quran (IIQ) Jakarta
}

\author{
Maria Ulfah \\ Program Studi Ilmu Al-Qur'an dan Tafsir, Institut Ilmu Al-Qur'an, Jakarta, Indonesia \\ mukhtar_ikhsan@yahoo.com
}

\begin{abstract}
The Institute for Quranic Studies (IIQ) Jakarta is one of the Islamic universities in Indonesia that specifically concentrates on developing the knowledge of the Qur'an and hadith, including learning about nagham as one of the compulsory subjects in the curriculum. Nagham Al-Qur'an is a lesson on how to read the Qur'an with a melodious voice and rhythm according to maqamat arabia, while still guided by the rules of recitation. This study aims to determine the effectiveness of the nagham science curriculum at IIQ Jakarta on the success of students in learning the nagham of the Qur'an. The research method was carried out by analyzing the data on student test scores and interviews with students of the IIQ. The results showed that learning nagham science at the Institute of Al-Quran Science is still not effective, as evidenced by the results of the student exam scores which are mostly still lacking (87\%), while the average score is $9 \%$ and the good score is only $4 \% . \%$. Good student grades are supported by their talents, interests, learning tajwid and nagham early and often performing recitations in public.
\end{abstract}

Keywords: Institut Ilmu Al-Qur'an; Al-Qur'an; Nagham

\begin{abstract}
Abstrak
Institut Ilmu Al-Qur'an (IIQ) Jakarta adalah salah satu perguruan tinggi Islam di Indonesia yang secara khusus berkonsentrasi pada pengembangan ilmu Al-Qur'an dan hadis, termasuk pembelajaran tentang ilmu nagham sebagai salah satu mata kuliah wajib dalam kurikulum. Ilmu Nagham Al-Qur'an adalah ilmu yang mengajarkan bagaimana membaca Al-Qur'an dengan suara dan irama yang indah, dengan tetap memperhatikan ilmu tajwid. Penelitian bertujuan untuk mengetahui efektivitas kurikulum ilmu nagham di IIQ Jakarta terhadap keberhasilan mahasiswa dalam mempelajari nagham Al-Qur'an. Metode penelitian dilakukan dengan cara menganalisis data-data nilai hasil ujian mahasiswa serta kuesioner dengan mahasiswa Institut Ilmu Al-Qur'an. Hasil penelitian menunjukkan bahwa pembelajaran ilmu nagham di Institut Ilmu Al-Quran masih belum efektif, terbukti dari hasil nilai ujian mahasiswa yang sebagian besar masih kurang (87\%), sedangkan nilai sedang sebanyak $9 \%$ dan nilai baik hanya sebanyak 4\%. Nilai mahasiswa yang baik didukung oleh adanya bakat, minat, belajar tajwid dan nagham lebih awal serta sering tampil tilawah Al-Qur'an di depan umum.
\end{abstract}

Kata kunci: Institut Ilmu Al-Qur'an; Al-Qur'an; Nagham 


\section{Pendahuluan}

Indonesia adalah salah satu negara yang paling aktif mengirimkan peserta dalam ajang Musabaqah Tilawatil Qur'an (MTQ) tingkat internasional dan selalu meraih prestasi tingkat dunia, namun bila ditilik dari segi akademis masih sangat miskin peneliti maupun literatur, yang secara khusus berkonsentrasi pada pengembangan seni membaca Al-Qur'an dengan lagu. Institut Ilmu Al-Qur'an (IIQ) sebagai salah satu perguruan tinggi Islam di Indonesia, yang secara khusus berkonsentrasi pada pengembangan ilmu Al-Qur'an dan hadis, menjawab masalah di atas dengan menjadikan pembelajaran tentang ilmu nagham, sebagai salah satu mata kuliah wajib dalam kurikulum yang diterapkan.

Beberapa penelitian yang penulis temukan berkaitan dengan metode pembelajaran nagham, hanya membahas seputar pembelajaran ilmu nagham di madrasah-madrasah maupun pesantren dengan metode sederhana, yang dari satu institusi ke institusi lainnya berbeda, dan penelitian-penelitian tersebut masih berupa makalah, skripsi dan tesis yang pembahasannya masih sederhana.

Rurin (2018) dalam tulisannya yang berjudul: Resepsi Al-Qur'an dalam Tradisi Pesantren di Indonesia: Studi Kajian Nagham Al-Qur'an di Pesantren Tarbiyatul Qur'an Ngadiluweh Kediri, mengkaji tentang proses transformasi pengajaran ilmu nagham di pondok pesantren Tarbiyatul Qur'an Ngadiluweh Kediri. Pengajaran ilmu nagham yang dilakukan di PP. Tarbiyatul Qur'an menunjukkan bahwa, gaya bacaan Al-Qur'an yang dibaca oleh Qari' dipengaruhi unsur internal dan eksternal. Unsur eksternal meliputi quranic competition dan pubic relation, sedangkan unsur internal yakni spiritual aesthetic meliputi puasa Dawud, doa 'Ain Al-Qur'an, mahabbah Asma Nabi Yusuf dan Adam a.s, serta puasa 7 hari nyuprih suara Nabi Daud a.s. Berbagai hal tersebut dilakukan sebagai bentuk usaha memperindah bacaan Al-Qur'an.

Dahlan (2000) menulis disertasi dengan judul: "Metode Pembelajaran dan Pengajaran Tarannum di Maktab: Suatu Kajian dari Segi Keberkesanan". Penelitian ini berkonsentrasi pada kemajuan metode pengajaran yang digunakan oleh guru-guru asrama perguruan Islam, khususnya guru-guru yang mengajar pada subjek tarannum (nagham) untuk Kelas Kemahiran Al-Qur'an (KKQ).

Ramadhani (2019) dalam tesisnya yang berjudul: "Efektivitas Pembelajaran Tilawah dalam Meningkatkan Kemampuan Seni Baca Al-Qur'an di UKM Hiqma UIN Raden Intan Lampung. Dalam kajian ini penulis berkonsentrasi meneliti standar mutu pembelajaran tilawah di UKM Hiqma UIN Raden Intan, untuk kemudian dilihat efektivitas dari metode pembelajaran yang diterapkan.

Arieska (2019) membuat tesis yang berjudul: Pembelajaran Seni Baca Al-Qur'an di UKM Hiqma UIN Raden Intan Lampung. Berbeda dengan penelitian sebelumnya, yang juga ditulis oleh mahasiswa pascasarjana UIN Raden Intan Lampung yang membahas 
tentang standar mutu dan efektivitas pembelajaran tilawah di UKM yang sama. Arieska dalam penelitiannya lebih berfokus pada hal sederhana, yaitu untuk mengetahui lebih dalam, bagaimana proses pembelajaran tilawah yang dilakukan oleh UKM tersebut, tanpa menyentuh aspek-aspek yang berkaitan dengan kurikulum.

Arieska menemukan empat kesimpulan besar yang meliputi: pertama dari segi materi yang diajarkan. Materi-materi pembelajaran tilawah yang diajarkan di UKM Hiqma meliputi tajwid, fasahah, teknik pernapasan, teknik vokal, maqamat (lagu) dan shalawat Nabi. Kedua, metode pembelajaran yang digunakan adalah metode sima'i dan tausyih. Ketiga, strategi yang digunakan adalah latihan pernapasan dan suara, yang menjadikan peserta setiap tahunnya dapat meraih kejuaraan di ajang MTQ. Keempat, pembelajaran yang dilakukan di UKM Hiqma diklasifikasikan dalam tiga kategori yaitu, dasar, menengah dan lanjutan. Hal ini dilakukan agar peserta mendapatkan materi yang sesuai dengan kemampuan awal mereka saat mendaftar.

Afrillia dkk. (2017) dalam penelitian mereka yang berjudul: Performances Measurement of Mel Frequency Ceptral Coefficient (MFCC) Method in Learning System of Al-Qur'an Based in Nagham Pattern Recognition meneliti lantunan Al-Qur'an atau yang lebih dikenal dengan istilah nagham dengan menggunakan metode Mel Frequency Ceptral Coefficient (MFCC), di mana metode ini digunakan untuk mengidentifikasi pola makhraj dan tajwid dalam membaca Al-Qur'an lewat sinyal yang diucapkan.

Penelitian tersebut menarik, sebab karakteristik pola nagham Al-Qur'an jauh lebih kompleks daripada pola makhraj dan tajwid. Dalam nagham, gelombang suara memiliki lebih banyak variasi. yang menyiratkan tingkat noice (kebisingan) jauh lebih tinggi dan memiliki durasi suara lebih lama. Pengujian data dalam penelitian ini diambil dengan pencatatan waktu yang nyata. Pengukuran evaluasi dalam kinerja sistem pola nagham Al-Qur'an, didasarkan pada parameter deteksi benar dan salah dengan akurasi 80\%.

Perbedaan penelitian penulis dengan penelitian-penelitian sebelumnya adalah, bahwa penelitian penulis dilakukan dengan subyek mahasiswa di suatu perguruan tinggi dengan kurikulum ilmu nagham yang sudah terstruktur, sedangkan obyek penelitian di tempat lain bukan mahasiswa di institusi perguruan tinggi yang sudah menerapkan kurikulum ilmu nagham.

Dalam penelitian ini bertujuan mengetahui efektivitas pembelajaran ilmu nagham di IIQ Jakarta terhadap keberhasilan mahasiswa dalam mempelajari nagham Al-Qur'an. Manfaat dari hasil penelitian ini antara lain: (1) menjadi sumbangan dalam pengembangan keilmuan yang berkaitan dengan bidang ilmu Al-Qur'an, khususnya ilmu nagham, sebagai salah satu bidang ilmu Al-Qur'an yang penting di Indonesia. (2) Menjadi rujukan yang dapat digunakan bagi yang berminat mempelajari ilmu nagham Al-Qur'an. Ketiga menghasilkan pembaca Al-Qur'an yang benar dan indah sebagai penyampai 
dakwah bi al-qalam, karena pembacaan Al-Qur'an yang baik dan indah merupakan salah satu media dalam dakwah Islam.

\section{Metode Penelitian}

Penelitian ini adalah penelitian kuantitatif deskriptif yang pengumpulan datanya melalui riset lapangan (field research) melalui metode kuesioner dan observasi terhadap mahasiswa-mahasiswa Institut Ilmu Al-Qur'an (IIQ) Jakarta yang mengambil mata kuliah ilmu nagham sebagai sampling yang telah mempelajari dan berhadapan langsung dengan kurikulum pembelajaran yang diterapkan. Sumber data dalam penelitian ini terdiri atas sumber data primer dan sumber data sekunder.

Sumber data utama dalam penelitian ini adalah hasil nilai akademik pembelajaran ilmu nagham yang telah diterapkan di Institut Ilmu Al-Qur'an (IIQ) Jakarta. Sedangkan sumber data lain berupa literatur-literatur yang terkait dengan ilmu nagham yang berguna dalam mendukung penelitian ini seperti jurnal-jurnal terkait ilmu Al-Qur'an atau yang berhubungan.

Penelitian dilakukan pada bulan Juli sampai Agustus 2020 di Institut Ilmu Al-Qur'an Jakarta. Data didapat dari nilai objektif hasil nilai akademik ujian mahasiswa IIQ semester delapan dan dari hasil kuesioner mahasiswa dengan sampel sebanyak 100 mahasiswa dari 300 mahasiswa. Perkiraan besar sampel minimal adalah sebanyak 96 orang. Dengan perkiraan drop out sebanyak 5\% maka dibutuhkan sampel sekitar 100 responden.

Nilai akademik hasil ujian mahasiswa dibagi menjadi tiga kelompok yaitu nilai baik (90-100), nilai sedang (80-89) dan nilai kurang (70-79). Pada sampel juga dilakukan kuesioner untuk meminta pendapat mahasiswa tentang berbagai hal yang menyangkut pembelajaran nagham di IIQ, misalnya bakat, minat, pengalaman belajar tajwid, nagham Al-Qur'an dan lain-lain.

Teknik penyajian analisis data yang dilakukan dalam penelitian ini menggunakan metode deskriptif-analisis dan induktif, yaitu mendeskripsikan data dan fakta-fakta yang ditemukan, kemudian disusul dengan analisis terhadap data-data tersebut sesuai dengan tujuan yang ingin dikemukakan oleh peneliti. Metode ini diharapkan mampu menyajikan deskripsi analisis data secara cermat dan jelas. Data disajikan dalam bentuk gambar, tabel dan narasi.

\section{Hasil dan Pembahasan}

\section{A. Temuan penelitian}

Telah diteliti sebanyak 100 responden yang merupakan mahasiswa IIQ semester empat, dengan rentang umur 19-20 tahun dan kesemuanya berjenis kelamin perempuan (untuk diketahui bahwa mahasiswa S1 IIQ semuanya adalah perempuan).

Dari hasil nilai akademik ujian mahasiswa, maka dikelompokkan menjadi tiga yaitu: 
1. Kelompok hasil ujian baik sebanyak 4 mahasiswa (4\%)

2. Kelompok hasil ujian sedang sebanyak $\mathbf{9}$ mahasiswa (9\%)

3. Kelompok hasil ujian kurang sebanyak $\mathbf{8 7}$ mahasiswa (87\%)

Hasil nilai akademik digabungkan dengan hasil kuesioner dapat dilihat pada Tabel 1.

Tabel 1. Data Gabungan Nilai Akademik dan Kuesioner

\begin{tabular}{|c|c|c|c|}
\hline Pertanyaan & $\begin{array}{c}\text { Kelompok } \\
\text { Nilai Baik }\end{array}$ & $\begin{array}{c}\text { Kelompok } \\
\text { Nilai Sedang }\end{array}$ & $\begin{array}{c}\text { Kelompok } \\
\text { Nilai Kurang }\end{array}$ \\
\hline 1. bakat terhadap & Ada: $100 \%$ & Ada: $89 \%$ & Ada: $20 \%$ \\
\hline nagham & Tidak ada: $0 \%$ & Tidak ada: $11 \%$ & Tidak ada: $80 \%$ \\
\hline 2. minat terhadap & Ada: $100 \%$ & Ada: $89 \%$ & Ada: $12 \%$ \\
\hline nagham & Tidak ada: $0 \%$ & Tidak ada: $11 \%$ & Tidak ada: $88 \%$ \\
\hline 3. Pernah belajar & Sudah: $100 \%$ & Sudah: 100\% & Sudah: 100\% \\
\hline tajwid sebelumnya & Belum: 0\% & Belum: 0\% & Belum: 0\% \\
\hline 4. Pernah belajar & Sudah: $100 \%$ & Sudah: $100 \%$ & Sudah: $56 \%$ \\
\hline nagham sebelumnya & Belum: 0\% & Belum: 0\% & Belum: 44\% \\
\hline 5. Nagham penting & $\begin{array}{l}\text { Penting: } 100 \% \\
\text { Tidak penting: } 0 \%\end{array}$ & $\begin{array}{l}\text { Penting: } 100 \% \\
\text { Tidak penting: } 0 \%\end{array}$ & $\begin{array}{l}\text { Penting: } 99 \% \\
\text { Tidak penting: } 1 \%\end{array}$ \\
\hline $\begin{array}{l}\text { 6. Waktu belajar } \\
\text { nagham } 4 \text { semester }\end{array}$ & $\begin{array}{l}\text { Cukup: } 25 \% \\
\text { Kurang: } 75 \%\end{array}$ & $\begin{array}{c}\text { Cukup: } 11 \% \\
\text { Kurang: } 89 \%\end{array}$ & $\begin{array}{c}\text { Cukup: } 35 \% \\
\text { Kurang: } 65 \%\end{array}$ \\
\hline $\begin{array}{l}\text { 7. Mampu } \\
\text { mempraktikkan } \\
\text { tujuh maqamat }\end{array}$ & $\begin{array}{l}\text { Sudah bisa: } 75 \% \\
\text { Belum bisa: } 25 \%\end{array}$ & $\begin{array}{l}\text { Sudah bisa: } 11 \% \\
\text { Belum bisa: } 89 \%\end{array}$ & $\begin{array}{l}\text { Sudah bisa: } 5 \% \\
\text { Belum bisa: } 95 \%\end{array}$ \\
\hline $\begin{array}{l}\text { 8. Praktik nagham } \\
\text { di depan umum }\end{array}$ & $\begin{array}{c}\text { Sering: } 25 \% \\
\text { Jarang: } 75 \% \\
\text { Tidak pernah: } 0 \%\end{array}$ & $\begin{array}{c}\text { Sering: } 0 \% \\
\text { Jarang: } 66 \% \\
\text { Tidak pernah: } 34 \%\end{array}$ & $\begin{array}{c}\text { Sering: } 2 \% \\
\text { Jarang: } 18 \% \\
\text { Tidak pernah: } 80 \%\end{array}$ \\
\hline 9. Mampu mengajar & Mampu: $75 \%$ & Mampu: $10 \%$ & Mampu: $5 \%$ \\
\hline kepada murid & Belum mampu: $25 \%$ & Belum mampu: 90\% & Belum mampu: 95\% \\
\hline 10.Cara mudah & Langsung ayat: $50 \%$ & Langsung ayat: $56 \%$ & Langsung ayat: $60 \%$ \\
\hline $\begin{array}{l}\text { 11. Kendala dalam } \\
\text { belajar nagham }\end{array}$ & $\begin{array}{l}\text { Suara tdk. lentur: } 0 \% \\
\text { Napas pendek: } 100 \% \\
\text { Suara tdk bening: } 0 \% \\
\text { Nada terbatas: } 50 \%\end{array}$ & $\begin{array}{c}\text { Suara tidak } \\
\text { lentur: } 66 \% \\
\text { Napas pendek: } 77 \% \\
\text { Suara tidak bening: } 22 \% \\
\text { Nada terbatas : } 22 \%\end{array}$ & $\begin{array}{c}\text { Suara tidak } \\
\text { lentur: } 66 \% \\
\text { Napas pendek: } 66 \% \\
\text { Surat tidak } \\
\text { bening: } 65 \% \\
\text { Nada terbatas: } 46 \%\end{array}$ \\
\hline 12. Belajar not balok & Pernah: 0 \% & Pernah: 55 \% & Pernah: $18 \%$ \\
\hline sebelum masuk IIQ & Belum pernah:100 \% & Belum pernah: $45 \%$ & Belum pernah: $82 \%$ \\
\hline 13. Belajar nagham & Setuju: $75 \%$ & Setuju: $88.8 \%$ & Setuju: $83 \%$ \\
\hline dengan not balok & $\begin{array}{l}\text { Tidak setuju: } 25 \% \\
\text { Juara MTQ: } 0 \%\end{array}$ & $\begin{array}{l}\text { Tidak setuju: } 11.2 \% \\
\text { Juara MTQ: } 44.4 \%\end{array}$ & $\begin{array}{l}\text { Tidak setuju: } 17 \% \\
\text { Juara MTQ: } 10 \%\end{array}$ \\
\hline 14. Hal pendorong & Mengajar: $75 \%$ & Mengajar: 77.7 \% & Mengajar: 46\% \\
\hline belajar nagham & $\begin{array}{l}\text { Syarat lulus IIQ: } 0 \% \\
\text { Ketenangan jiwa:75 \% }\end{array}$ & $\begin{array}{l}\text { Syarat lulus IIQ: } 0 \% \\
\text { Ketenangan jiwa: } 55 \%\end{array}$ & $\begin{array}{c}\text { Syarat lulus IIQ: } 9 \% \\
\text { Ketenangan jiwa: } 74 \%\end{array}$ \\
\hline 15.Juara MTQ & Sudah pernah: $75 \%$ & Sudah pernah: 75\% & Sudah pernah: $10 \%$ \\
\hline sebelum masuk IIQ & Belum pernah: $25 \%$ & Belum pernah: $25 \%$ & Belum pernah: $90 \%$ \\
\hline 16. Juara MTQ & Sudah pernah: $75 \%$ & Sudah pernah: $75 \%$ & Sudah pernah: $5 \%$ \\
\hline setelah masuk IIQ & Belum pernah: $25 \%$ & Belum pernah: $25 \%$ & Belum pernah: $95 \%$ \\
\hline $\begin{array}{l}\text { 17. Penunjang } \\
\text { sukses dalam MTQ* }\end{array}$ & $\begin{array}{c}\text { Tajwid: } 50 \% \\
\text { Variasi lagu: } 75 \% \\
\text { Dzauq: } 0 \%\end{array}$ & $\begin{array}{c}\text { Tajwid: } 77 \% \\
\text { Variasi lagu: } 55.5 \% \\
\text { Dzauq: } 77 \%\end{array}$ & $\begin{array}{c}\text { Tajwid: } 87 \% \\
\text { Variasi lagu: } 67 \% \\
\text { Dzauq: } 35 \%\end{array}$ \\
\hline
\end{tabular}




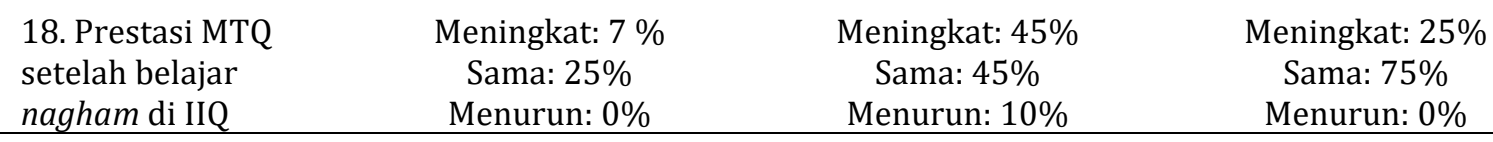

Catatan: Total bisa lebih dari 100\% karena mahasiswa boleh memilih lebih dari satu jawaban.

\section{B. Pembahasan}

Dari nilai akademik hasil ujian mahasiswa terlihat bahwa mahasiswa yang mempunyai nilai baik hanya 4 orang (4\%), nilai sedang 9 orang (9\%) dan nilai kurang 87 orang $(87 \%)$. Data tersebut menunjukkan bahwa proses pembelajaran ilmu nagham di Institut Ilmu Al-Qur'an Jakarta belum efektif, artinya belum mencapai sasaran yang ditentukan. Banyak faktor yang memengaruhi efektivitas pembelajaran sehingga mahasiswa belum mencapai suatu prestasi yang diinginkan.

Prestasi belajar merupakan hasil penilaian atas kemampuan, kecakapan dan keterampilan tertentu yang dipelajari selama masa belajar. Proses belajar mengajar yang baik akan sangat berpengaruh terhadap tingkat keberhasilan mahasiswa yang digambarkan dengan prestasi akademik.

Edi Sutarto menyatakan bahwa keberhasilan siswa dalam belajar dapat dipengaruhi oleh faktor internal dan eksternal. Faktor internal berasal dari dalam diri sendiri yang berupa faktor biologis seperti faktor kesehatan dan faktor psikologis seperti kecerdasan, bakat, minat, perhatian serta motivasi. Sedangkan faktor eksternal yaitu faktor yang berhubungan dengan lingkungan sekolah. (Edi Sutarto, 2011)

Pada Tabel 1 terlihat pada semua kelompok nilai, semakin tinggi bakat maka semakin baik nilai naghamnya. Setiap orang terlahir dengan membawa berbagai macam potensi. Potensi yang dimilikinya maka akan berkembang sesuai dengan bakat yang dimilikinya. Bakat merupakan kemampuan yang sudah melekat (inherent) pada diri seseorang yang dibawanya sejak lahir dan berkaitan dengan struktur otak (Putra, 2013).

Keberhasilan siswa dalam belajar dapat dipengaruhi oleh faktor internal dan eksternal. Faktor internal berasal dari dalam diri sendiri yang berupa faktor biologis seperti faktor kesehatan dan faktor psikologis seperti kecerdasan, bakat, minat, perhatian serta motivasi. Sedangkan faktor eksternal yaitu faktor yang berhubungan dengan lingkungan sekolah (Ali \& Asrori, 2014).

Bakat perlu digali dan dikembangkan agar dapat terwujud. Bakat itu bermacammacam jenisnya, ada yang memiliki bakat dalam seni musik, seni bela diri, pembawa acara, olahraga, dan sebagainya termasuk dalam bidang seni baca Al-Qur'an. Tetapi tidak semua bakat dapat teridentifikasi karena kurangnya kesadaran akan bakat yang dimilikinya. Karena tidak terfasilitasinya kebutuhan wadah terhadap bakat tersebut maka tidak semua bakat dapat tersalurkan dengan baik dan maksimal. Tidak menutup 
kemungkinan bakat tersebut akan menjadi bakat terpendam, tanpa dapat teraktualisasikan dalam kehidupan.

Winkel dan Hastuti (2005) menyatakan bahwa bakat khusus adalah kemampuan yang menonjol di suatu bidang usaha kognitif, bidang keterampilan, atau bidang kesenian. Sekali terbentuk, suatu bakat khusus menjadi bekal yang memungkinkan untuk memasuki berbagai bidang pekerjaan tertentu, dan mencapai tingkatan yang lebih tinggi dalam suatu jabatan.

Dari Tabel 1 terlihat pada semua kelompok nilai, makin tinggi minat juga makin tinggi nilai ujian naghamnya. Minat biasanya disandingkan dengan bakat. Minat adalah sebuah dorongan yang berasal dari dalam diri seseorang atau sesuatu faktor yang bisa menimbulkan ketertarikan atau perhatian secara selektif yang bisa menyebabkan dipilihnya suatu objek atau kegiatan yang menguntungkan, menyenangkan, dan lamalama akan mendatangkan keputusan dalam dirinya. (Munandar, 1999) Minat harus dikelola dengan baik agar dapat tersalurkan secara maksimal terhadap hal yang disenanginya. Di samping itu, minat yang besar terhadap suatu hal akan memberikan persentase peluang yang besar untuk perubahan dan keberhasilan pencapaian tujuan yang dimiliki oleh individu. Minat ini sangat penting untuk mendorong individu menjadi lebih selektif dan ekspresif dalam menunjukkan suatu hal yang disenangi sehingga akan menimbulkan rasa puas terhadap hal tersebut.

Minat merupakan salah satu faktor yang dapat memengaruhi hasil belajar siswa. Semakin tinggi minat siswa, maka akan meningkatkan motivasi siswa dalam belajar. Ahmad mendefinisikan minat sebagai kecenderungan untuk selalu memperhatikan dan mengingat sesuatu secara terus-menerus (Abror, 2001). Minat berkaitan dengan perasaan senang. Dengan kata lain, orang yang berminat terhadap sesuatu maka sikapnya akan senang terhadap sesuatu itu. Dalam proses pembelajaran, minat siswa dapat diukur dalam beberapa indikator seperti yang dinyatakan oleh Abror yang menjelaskan indikator minat belajar siswa dalam mengikuti suatu mata pelajaran di antaranya: 1) perasaan senang, 2) perhatian, 3) perasaan tertarik, 4) giat belajar dan 5) mengerjakan tugas. Slameto menyatakan bahwa minat besar pengaruhnya terhadap belajar, karena bila bahan pelajaran yang dipelajari tidak sesuai dengan minat siswa, siswa tidak akan belajar dengan sebaik-baiknya (Slameto, 2010).

Tulus menyatakan bahwa prestasi belajar adalah penguasaan pengetahuan atau keterampilan yang dikembangkan oleh mata pelajaran, lazimnya ditunjukkan dengan nilai tes atau angka nilai yang diberikan oleh guru. Minat siswa dalam mengikuti pembelajaran merupakan suatu faktor penting dalam upaya peningkatan prestasi belajar sebagai tolok ukur keberhasilan proses pembelajaran (Tulus, 2004).

Hasil penelitian oleh Irawan \& Saputra (2019) menunjukkan bahwa: 1) terdapat korelasi positif dan signifikan antara minat belajar dan prestasi siswa; 2) faktor yang 
mendukung peningkatan minat siswa di antaranya: motivasi dari orang tua, guru, dan lingkungan tempat tinggal siswa; 3) faktor penghambat dalam peningkatan minat siswa antara lain: masih kurangnya sarana dan prasarana sekolah dalam upaya meningkatkan minat siswa untuk belajar.

Pada tabel 1 di atas terlihat bahwa pada kelompok dengan nilai baik, sedang maupun kurang, kesemuanya sudah pernah belajar ilmu tajwid sebelum kuliah di IIQ. Hal tersebut tidak mengherankan karena ilmu tajwid sangat diperlukan guna bisa membaca Al-Qur'an dengan baik. Semua mahasiswa berasal dari keluarga muslim, maka belajar ilmu tajwid adalah merupakan keharusan bagi keluarga tersebut agar dapat membaca Al-Qur'an dengan baik.

Pada kelompok nilai baik dan sedang, semuanya sudah pernah belajar ilmu nagham sebelum masuk IIQ. Berarti pada saat kuliah di IIQ mereka sudah pernah mengenal pelajaran nagham sehingga waktu belajar di IIQ tinggal mengulang apa yang telah dipelajari sebelumnya. Sedangkan pada kelompok nilai kurang, 56 \% mahasiswanya belum pernah belajar nagham, yang berarti pada waktu menjadi mahasiswa IIQ baru belajar nagham. Yang menjadi pertanyaan adalah bagi kelompok nilai sedang dan kurang, ada yang sudah pernah belajar nagham sebelum kuliah di IIQ, mengapa nilainya masih sedang dan kurang. Mungkin ada beberapa faktor yang memengaruhi:

1. Faktor dosen / pengajar. Dosen pengajar ilmu nagham di IIQ terdiri dari tim pengajar yang pada umumnya merupakan qariah yang pernah menjuarai MTQ tingkat nasional maupun internasional. Kemampuan mereka secara individual dalam ilmu nagham tidak bisa diragukan lagi. Hanya saja cara penyampaiannya kepada mahasiswa apakah sudah efektif, masih perlu evaluasi lebih lanjut.

2. Faktor mahasiswa. Faktor dari mahasiswa meliputi faktor bakat, minat, motivasi belajar, dan lain-lain.

3. Faktor materi pembelajaran ilmu nagham. Faktor ini meliputi materi yang diajarkan dan metode pembelajarannya. Pemilihan materi maupun metode pembelajaran ilmu nagham juga berpengaruh terhadap hasil pembelajaran.

Bagi semua kelompok mahasiswa yang diteliti, mereka berpendapat bahwa ilmu nagham sangat penting untuk dipelajari. Mereka semua mengetahui bahwa IIQ adalah perguruan tinggi Islam dengan Visi : "Menjadi Pusat Studi dan Riset Al-Qur'an Terbaik dan Terdepan di Dunia Tahun 2028." Oleh karena itu belajar ilmu nagham adalah penting guna mendukung Visi dari IIQ. Seharusnya dengan visi tersebut maka para mahasiswa seharusnya timbul minatnya untuk belajar ilmu nagham sehingga mereka akan belajar ilmu nagham dengan sebaik-baiknya.

Sebagai perguruan tinggi keislaman, Institut Ilmu Al-Qur'an mengadopsi kurikulum yang ditentukan oleh Kementerian Agama cq Kopertais. Karena banyak yang harus diajarkan guna memenuhi ketentuan dari Kementerian Agama, maka alokasi pengajaran 
ilmu nagham hanya 4 semester atau 8 SKS (Satuan Kredit Semester). Pada kelompok dengan nilai baik 75 \% mengatakan kurang waktu, pada kelompok nilai sedang $89 \%$ sedangkan pada kelompok nilai kurang 65 \%. Jadi pada semua kelompok, waktu pembelajaran selama 4 semester dirasakan masih kurang. Masalahnya adalah, telah banyaknya jumlah SKS yang ditentukan oleh Kementerian Agama sehingga kalau alokasi waktu pembelajaran ilmu nagham diperpanjang, akan menambah beban SKS bagi mahasiswa.

Dalam kitab Ta'lim Al-Mutaallim, Az-Zarnuji menuliskan dua bait syair dari Sayyidina 'Ali bin Abi Thalib Ra., yang berbunyi:

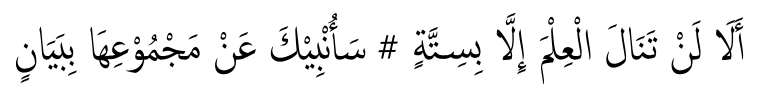

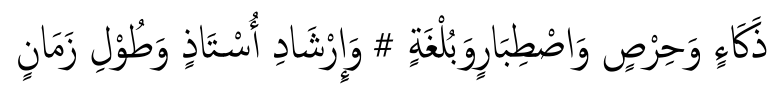

"Ingatlah! Engkau tidak akan mendapatkan ilmu kecuali dengan memenuhi enam syarat, Saya akan beritahukan keseluruhannya secara rinci, yaitu: kecerdasan, sungguh-sungguh, kesabaran, ada biaya, ada bimbingan guru, dan waktu yang lama." (Said, 1997)

Setelah belajar ilmu nagham di IIQ, kemampuan untuk mempraktikkan ilmu nagham dengan tujuh maqamat untuk diterapkan dalam ayat, pada kelompok nilai baik adalah 100\%, pada kelompok nilai sedang $11 \%$ sedangkan pada kelompok nilai kurang adalah $5 \%$. Kemampuan membuat tujuh maqamat dalam waktu yang ditentukan berarti mereka bisa membuat variasi lagu sehingga lengkap tujuh maqamat. Dalam musabaqah tilawatil Al-Qur'an (MTQ), hal tersebut merupakan salah satu unsur penilaian yang sangat penting. Sebagian besar mahasiswa masih mengalami kesulitan dalam mempraktikkan lagu dalam ayat, untuk menyusun komposisi tujuh lagu dalam maqamat Arabia. berarti memang hasil pembelajaran nagham belum memuaskan.

Yang dimaksud praktik maqamat di tempat umum adalah membaca Al-Qur'an dengan lagu di depan khalayak ramai, misalnya diundang pada waktu hari-hari besar Islam, acara ulang tahun, pengajian, dll. Bilamana seseorang diundang untuk membaca Al-Qur'an di depan umum, sudah barang tentu akan mempersiapkan dengan baik bacaannya. Semakin sering tampil di depan umum maka semakin sering berlatih, sehingga semakin mahir dalam tilawah Al-Qur'an. Kelompok nilai baik lebih sering tampil dibanding kelompok nilai sedang dan kurang.

Selama ini khususnya di Indonesia, cara belajar ilmu nagham ada dua acara yaitu secara langsung, artinya suatu ayat Al-Qur'an dilagukan kemudian ditirukan oleh para murid. Sedangkan cara lain adalah melalui tausyih, yaitu pola lagu maqamat pada kalimat kemudian maqamat tersebut bisa diaplikasikan pada suatu ayat, tentunya dengan tetap memperhatikan tajwidnya. Pada kelompok nilai baik, sedang maupun kurang, semua 
pendapatnya hampir yaitu belajar secara langsung praktik pada ayat maupun melalui tausyih sama mudahnya.

Pada semua sistem pembelajaran suatu ilmu pasti ada kendala-kendala yang menghambat sehingga menjadi tidak lancar. Dalam mempelajari ilmu nagham, beberapa hal yang bisa menghambat antara lain suara tidak lentur, napas pendek, suara tidak bening dan nada terbatas. Pada semua kelompok nilai, napas pendek merupakan kendala yang paling dominan dalam belajar ilmu nagham.

Bagi semua yang belajar tentang ilmu musik atau seni suara, belajar not balok merupakan ilmu untuk memudahkan belajar suatu lagu sehingga bisa dipelajari dengan mudah. Pada kelompok nilai baik, nilai sedang dan nilai kurang, sebagian besar mengatakan belum pernah belajar not balok. Di tingkat pendidikan menengah, not balok biasanya diajarkan dalam mata pelajaran seni suara atau bisa juga pada kursus-kursus musik bagi pencinta musik.

Dalam rangka memperbaiki efektivitas dalam pembelajaran ilmu nagham, menggunakan sarana not balok merupakan salah satu alternatif. Pada penelitian ini semua kelompok setuju untuk menggunakan not balok sebagai sarana untuk memudahkan belajar ilmu nagham. Salah satu kendala dalam hal ini adalah akan menambah jam pelajaran sehingga harus dibicarakan dengan pihak pendidikan, dalam hal ini rektor, wakil rektor bidang akademik, dekan, wakil dekan bidang akademik, dll.

Dalam suatu kegiatan belajar biasanya ada faktor-faktor yang mendorong kegiatan belajar tersebut sehingga lebih bersemangat. Dalam hal belajar ilmu nagham mungkin ada beberapa faktor pendorong antara lain: ingin mengajarkan kepada orang lain, menjadi juara/qariah terbaik dalam MTQ, memenuhi kompetensi sebagai lulusan IIQ, dan agar jiwa menjadi tenang.

Sebelum menjadi mahasiswa IIQ, pada kelompok nilai baik dan sedang, semuanya atau sebagian besar sudah menjadi juara MTQ di berbagai tingkatan, sedangkan pada kelompok nilai kurang hanya sebagian kecil yang pernah menjadi juara MTQ. Seseorang menjadi juara MTQ berarti sudah memahami ilmu nagham, sehingga mempunyai nilai baik atau sedang.

Setelah menjadi mahasiswa IIQ, keadaannya sama dengan sebelum masuk IIQ. Artinya pada kelompok nilai baik dan sedang, sebagian besar sudah menjadi juara MTQ di berbagai tingkatan, sedangkan pada kelompok nilai kurang hanya sebagian kecil yang sudah pernah menjadi juara MTQ.

Setelah belajar nagham di IIQ, prestasi dalam MTQ meningkat pada semua kelompok nilai. Data tersebut menunjukkan bahwa belajar ilmu nagham di IIQ bermanfaat untuk meningkatkan prestasi bagi yang mengikuti MTQ. 
Dari gabungan hasil nilai akademik ilmu nagham mahasiswa dan kuesioner terlihat bahwa mahasiswa yang mempunyai nilai baik sebanyak 4 orang (4\%) seluruhnya mempunyai karakter yang sama yaitu: mempunyai bakat dalam nagham Al-Qur'an; mempunyai minat dalam nagham Al-Qur'an; pernah belajar ilmu tajwid sebelum kuliah di IIQ; pernah belajar nagham sebelum kuliah di IIQ; menganggap penting pelajaran ilmu nagham; mampu menyusun satu bacaan maqra dengan tujuh maqamat; sering mempraktikkan tilawah Al-Qur'an di depan umum; sudah bisa mengajarkan kepada murid; sudah pernah menjadi juara MTQ sebelum masuk IIQ; sudah pernah menjadi juara MTQ setelah masuk IIQ; dan meningkat pengetahuannya tentang ilmu nagham setelah kuliah di IIQ.

\section{Kesimpulan}

Penelitian ini menunjukkan bahwa hasil pembelajaran ilmu nagham di Institut Ilmu Al-Qur'an (IIQ) masih belum mencapai hasil yang diinginkan, terbukti dari hasil nilai akademik ujian mahasiswa dengan nilai baik sebanyak 4 orang (4\%), nilai sedang 9 orang (9\%) dan nilai kurang sebanyak 87 orang (87\%). Karakteristik mahasiswa dengan nilai kurang secara umum adalah tidak mempunyai minat dan bakat dalam nagham Al-Qur'an, belum pernah belajar nagham sebelum masuk IIQ dan belum pernah mengikuti atau menjadi juara MTQ.

\section{Daftar Pustaka}

Abror A. R. (2001). Psikologi Pendidikan. Nur Cahaya.

Afrillia, Y., Mawengkang, H., Ramli, M., Fadlisyah, \& Fhonna, R. P. (2017). Performance Measurement OfMel Frequency Ceptral Coefficient (MFCC) Method In Learning System Of Al- Qur'an Based InNaghamPattern Recognition. Journal of Physics: Conference Series, 930, 012036. https://doi.org/10.1088/1742-6596/930/1/012036

Ali, M., \& Asrori, M. (2014). Psikologi Remaja: Perkembangan Peserta Didik. PT Bumi Aksara.

ARIESKA, R. (2019). Pembelajaran Seni Baca Al-Qur 'An Di UKM HIQMA UIN Raden Intan Lampung [Masters, UIN Raden Intan Lampung]. http://repository.radenintan.ac.id/5696/

Dahlan, Z. M. (2000). Metode Pembelajaran dan Pengajaran Tarannum di Maktab: Suatu Kajian dari Segi Keberkesanan. Akademi Pengajian Islam, Universiti Malaya.

Irawan, D., \& Saputra, R. R. (2019). Analisis Hubungan Minat Belajar Dan Prestasi Belajar Siswa Pada Mata Pelajaran Al-Qur'an Hadist. AULADUNA: Jurnal Pendidikan Dasar Islam, 6(1), 7-13. https://doi.org/10.24252/auladuna.v6i1a2.2019

Munandar, U. (1999). Pengembangan Kreativitas Anak Berbakat. Rineka Cipta.

Putra, S. R. (2013). Panduan Pendidikan Berbeda Bakat Siswa. Diva Press.

Ramadhani, k. R. (2019). Efektivitas pembelajaran tilawah dalam meningkatkan kemampuan seni baca qur'an di UKM HIQMA UIN Raden Intan Lampung [Masters, UIN Raden Intan Lampung]. http://repository.radenintan.ac.id/6067/

Rurin, A. M. (2018). Resepsi Alquran Dalam Tradisi Pesantren Di Indonesia (Studi Kajian 
Nagham Alquran Di Pondok Pesantren Tarbitayul Quran Ngadiluweh Kediri). AlBayan: Jurnal Studi Ilmu Al-Qur'an dan Tafsir, 3(2).

Said, I. G. (1997). Ta'limul Muta'allim Thariqat Ta'allum. Diyantama.

Slameto. (2010). Belajar dan Faktor-Faktor yang Mempengaruhinya.

Tulus, T. (2004). Peran Disiplin pada Perilaku dan Prestasi Belajar. Grasindo.

Winkel, W. S., \& Hastuti, S. (2005). Bimbingan dan Konseling di Institusi Pendidikan. PT. Grasindo. 